\title{
Penyuluhan dan Pedampingan Penyusunan Pengelolaan Keuangan Panti Asuhan "Darus - Shiddiqien NW" Mertak Paok, Desa Mekar Bersatu Kecamatan Batukliang Kabupaten Lombok Tengah
}

\author{
Endar Pituringsih*, Titiek Herwanti, Lilik Handajani \\ Fakultas Ekonomi dan Bisnis Universitas Mataram, Mataram, Indonesia
}

Article history

Received: 06-11-2020

Revised: 20-11-2020

Accepted: 24-11-2020

*Corresponding Author: Endar Pituringsih, Fakultas Ekonomi dan Bisnis Universitas Mataram, Mataram Nusa Tenggara Barat, Indonesia

Email: endar07ringsih@gmail.com

\begin{abstract}
The counseling and training activities on the preparation of financial management at the DarusShiddiqien NW Mertak Paok Reformatory in Central Lombok Regency aim to provide understanding and training to orphanage administrators in Central Lombok Regency. In addition, this training was conducted to provide knowledge to orphanage administrators about the importance of making financial reports, so that funds from donors can be managed properly. In the end, this activity is expected to produce human resources capable of making bookkeeping and financial management. This training activity will be aimed at administrators of the DarusShiddiqien NW Mertak Paok Islamic Boarding School in Central Lombok Regency. The implementation of the activity is carried out with the approach of presenting material relevant to the needs of the orphanage administrators according to PSAK 45. Another hope of this activity can be a means of carrying out community service activities, in particular providing counseling and training in preparing financial reports.
\end{abstract}

Keywords: accountability; financial; management; reformatory; transparency

Abtrak: Kegiatan penyuluhan dan pelatihan tentang penyusunan pengelolaan keuangan Pondok Pesantren DarusShiddiqien NW Mertak Paok Kabupaten Lombok Tengah ini bertujuan untuk memberikan pemahaman dan pelatihan kepada pengurus panti asuhan yang berada di Kabupaten Lombok Tengah. Selain itu, pelatihan ini dilakukan untuk memberikan pengetahuan kepada pengurus panti asuhan tentang pentingnya membuat laporan keuangan, sehingga dana dari donatur dapat dikelola dengan baik. Pada akhirnya kegiatan ini diharapkan menghasilkan SDM yang mampu untuk membuat pencatatan pembukuan dan pengelolaan keuangan. Kegiatan pelatihan ini akan ditujukan pada pengurus Pondok Pesantren DarusShiddiqien NW Mertak Paok Kabupaten Lombok Tengah. Pelaksanaan kegiatan dilakukan dengan pendekatan pemberian materi yang relevan dengan kebutuhan pengurus panti asuhan sesuai PSAK 45. Harapan lain dari kegiatan ini dapat menjadi sarana untuk melaksanakan kegiatan pengabdian kepada masyarakat, khususnya memberikan penyuluhan dan pelatihan penyusunan laporan keuangan.

Kata Kunci: akuntabilitas; keuangan; pengelolaan; panti asuhan; transparansi

\section{PENDAHULUAN}

Suatu organisasi nirlaba memperoleh sumber dayanya dari penyumbang yang tidak mengharapkan imbalan, menghasilkan barang/jasa tanpa bertujuan memupuk laba, dan tidak memiliki 
bagian kepemilikan seperti halnya organisasi bisnis (Nainggolan, 2005). Pada beberapa bentuk entitas nirlaba, kebutuhan modalnya didanai dari hutang, dan kebutuhan operasinya didanai dari pendapatan atas jasa yang diberikan kepada masyarakat. Hal lain yang membedakan organisasi nirlaba dengan organisasi bisnis adalah pada bagian laporan keuangannya, yaitu adanya pemisahan dana yang diterima oleh entitas nirlaba (Fahmi, 2016). Aset neto harus disajikan terpisah baik yang terikat maupun yang tidak terikat, maka harus ada pelaporan khusus dan terpisah.

Pada dasarnya, tujuan organisasi nirlaba mengarah pada manfaat ekonomis, sosial, pendidikan atau spiritual dari individu atau golongan yang tidak memiliki kepentingan dalam kepemilikan atau investasi pada organisasi. Organisasi nirlaba akan dituntut untuk senantiasa menyiapkan rencanarencana serta program dan penganggarannya secara berkesinambungan. Tuntutan akan akuntabilitas memadai, untuk organisasi non laba bukanlah hal yang mudah, seringkali bendahara organisasi nirlaba adalah seseorang yang punya pengalaman dalam bidang akuntansi bisnis, tetapi tidak memiliki pelatihan/ketrampilan khusus dalam akuntansi sosial, sehingga pengelola organisasi nirlaba disarankan dapat menyusun laporan keuangan yang sesuai dengan standar yang berlaku (Fitria, 2017). Laporan keuangan merupakan salah satu bentuk informasi akuntansi yang digunakan sebagai bentuk pertanggungjawaban manajemen atas pengelolaan sumber daya. Bagi organisasi nirlaba, laporan keuangan dibutuhkan untuk memberikan informasi akuntansi bagi para donatur, yayasan, kreditur, anggota organisasi, dan pihak lainnya.

Laporan keuangan merupakan salah satu bentuk informasi akuntansi yang digunakan sebagai bentuk pertanggungjawaban manajemen atas pengelolaan sumber daya. Bagi organisasi nirlaba, laporan keuangan dibutuhkan untuk memberikan informasi akuntansi bagi para donatur, yayasan, kreditur, anggota organisasi, dan pihak lainnya (Dewi, 2020). Entitas nirlaba memperoleh sumber daya dari sumbangan, yaitu dalam kasus ini ialah para donatur dan tidak ditunjukkan dalam bentuk kepemilikan saham, sehingga pelaporan keuangan menjadi hal yang penting bagi entitas ini sebagai bentuk pertanggungjawaban bagi para pihak yang telah menyediakan sumber daya bagi organisasi guna membangun kepercayaan.

Salah satu bentuk organisasi nirlaba di tengah masyarakat adalah yayasan pondok pesantren. Contoh konkret pembangunan Pondok pesantren di tengah masyarakat ialah Pondok Pesantren DarusShiddiqien NW Mertak Paok Kabupaten Lombok Tengah yang didirikan Tahun 1960. Pondok Pesantren DarusShiddiqien NW merupakan salah satu organisasi yang memberikan pendidikan RA, MI, MTs, SMK dan MA. Pondok Pesantren ini dikelola dengan jumlah anak asuh sebanyak 705 orang. Pondok Pesantren ini tidak hanya bergerak di bidang pendidikan tapi juga sosial (lansia, asuhan keluarga, koperasi, wakaf, dll) serta bidang dakwah (majlis ta`lim dan kajian kitab kuning untuk santri).

Pengguna laporan keuangan akan menuntut beberapa hal dari organisasi nirlaba, yaitu transparansi, akuntabilitas, dan efisiensi penggunaan sumber daya. Di dalam Panti Asuhan DarusShiddiqien NW tidak terdapat bagian kepemilikan, sehingga transparansi menjadi hal yang penting mengingat sumber daya berasal dari para donatur dan masyarakat, sehingga para donatur berhak mengetahui secara terbuka pengelolaan sumber daya Pondok Pesantren. Pondok Pesantren juga memiliki tuntutan akuntabilitas, yaitu dengan memberikan pertanggungjawaban, menyajikan, melaporkan, dan mengungkapkan segala aktivitas guna membangun kepercayaan. Pondok Pesantren Darus Shiddiqien NW menginginkan organisasinya mampu untuk terus memberikan jasa dan mengelola sumber daya secara efisien dan efektif, dengan salah satu upayanya adalah meyakinkan publik bahwa usaha yang dilakukannya dapat dipertanggungjawabkan. Dari ketiga tuntutan tersebut, 
maka penyusunan laporan keuangan pada Pondok Pesantren Darus Shiddiqien NW sangat diperlukan. Pada Pondok pesantren belum memiliki laporan keuangan yang memadai. Pelaporan keuangan yang memadai berguna sebagai informasi akuntansi bagi kepentingan pihak-pihak yang menyediakan sumber daya bagi organisasi nirlaba. Berdasarkan analisis situasi diatas, maka dapat dirumuskan permasalahan yaitu 1) SDM yang dimiliki oleh panti asuhan terkait dengan pencatatan pembukuan dan pengelola keuangan, dimana kurangnya pemahaman bagaimana mengelola/menggunakan dana, 2) Penyusunan pelaporan yang masih belum berdasarkan pedoman PSAK 45 karena keterbatasan pengetahuan dan keterampilan dalam bidang akuntansi.

\section{METODE}

Adapun metode pelaksanaan kegiatan Pengabdian Pada masyarakat ini dilakukan dengan metode Ceramah, tutorial, dan diskusi. Dengan langkah-langkah kegiatan sebagai berikut :

1. Langkah 1 (Metode Ceramah)

Peserta diberikan penyuluhan tentang pedoman pengelolaan keuangan untuk organisasi nirlaba seperti pondok pesantren.

2. Langkah 2 (Metode Tutorial)

Peserta pelatihan diberikan latihan singkat tentang akuntansi dengan praktek secara langsung dengan cara melakukan pendampingan tentang cara membuat laporan keuangan untuk organisasi nirlaba.

3. Langkah 3 (Metode Diskusi)

Peserta diberikan kesempatan untuk menyampaikan dan mendiskusikan permasalahan yang dihadapi dalam pengelolaa keuangan.

\section{HASIL DAN PEMBAHASAN}

Kegiatan pengabdian dilakukan di Panti Asuhan Darrus-Shiddiqien NW Merta Paok pada hari Rabu 26 Agustus 2020 pada pukul 14.00 Wita. Peserta pengabdian dihadiri oleh 10 peserta pengurus Panti Asuhan Darrus-Shiddiqien NW Merta Paok. Sebelum kegiatan pengabdian dilakukan, tim pengabdian telah melakukan pemberitahuan informasi secara langsung kepada pimpinan panti asuhan yang kemudian disampaikan pada setiap pengurus panti asuhan. Selanjutnya kegiatan pengabdian ini dilakukan dengan mempresentasikan materi mengenai pengelolaan keuangan kepada peserta, yang dilanjutkan dengan sesi tanya jawab/diskusi antara pemateri dan peserta pengabdian.

Akuntansi untuk sektor publik adalah suatu proses pengumpulan, pengklasifikasian, analisis, dan pembuatan laporan pengelolaan keuangan dalam lembaga publik. Laporan pengelolaan keuangan ini nantinya digunakan lembaga publik untuk memberikan informasi keuangan pada pihak yang membutuhkan. Intinya, laporan pengelolaan keuangan ini sangat membantu saat ada pengambilan keputusan. Dalam melaksanakan pekerjaan, organisasi dan lembaga publik selalu dituntut agar pengelolaan biaya sosial dan ekonomi bisa lebih efisien. Jika tuntutan pertanggungjawaban publik oleh berbagai lembaga publik menguat, akuntansi sektor publik akan diakui sebagai ilmu untuk mengelola keuangan publik.

Akuntansi untuk sektor publik ini digunakan untuk transparansi kepada publik untuk memenuhi hak-hak publik. Sektor publik yang dimaksud dalam akuntansi ini terdiri dari lembaga pemerintah di daerah dan pusat dan lembaga non-pemerintah. Bahkan, rumah sakit dan lembaga pendidikan juga 
membutuhkan akuntansi jenis ini. Biasanya, proses pengklasifikasian dan analisis laporan pengelolaan keuangan yang dilakukan sektor publik berbeda dengan proses yang dilakukan sektor swasta. Perbedaan ini terjadi karena negara, khususnya organisasi pemerintah, tentu memiliki standar sistem akuntansi masing-masing. Jadi, proses tersebut harus disesuaikan dengan standar akuntansi yang dianut oleh lembaga.

Informasi laporan keuangan dihasilkan melalui proses akuntansi yang panjang, dimana proses ini mencakup beberapa tahapan yang harus dipenuhi guna bisa mendapatkan hasil laporan yang baik, valid, dan akuntabel. Tahapan inilah yang dinamakan sebagai siklus akuntansi. Pengertian siklus akuntansi adalah sebuah proses penyusunan suatu laporan keuangan yang harus bisa dipertanggungjawabkan dan diterima secara umum. Mulai dari prinsip-prinsip dan kaidah akuntansi, prosedur, metode, serta teknik yang berada di dalam lingkup akuntansi sepenuhnya dicatat dalam suatu periode tertentu. Pada umumnya, siklus akuntansi selalu dimulai dengan aktivitas transaksi sampai dengan pembuatan laporan keuangan perusahaan. Kemudian proses kembali dilanjutkan dengan adanya saldo yang ditutup dengan jurnal penutup atau sampai jurnal pembalik.

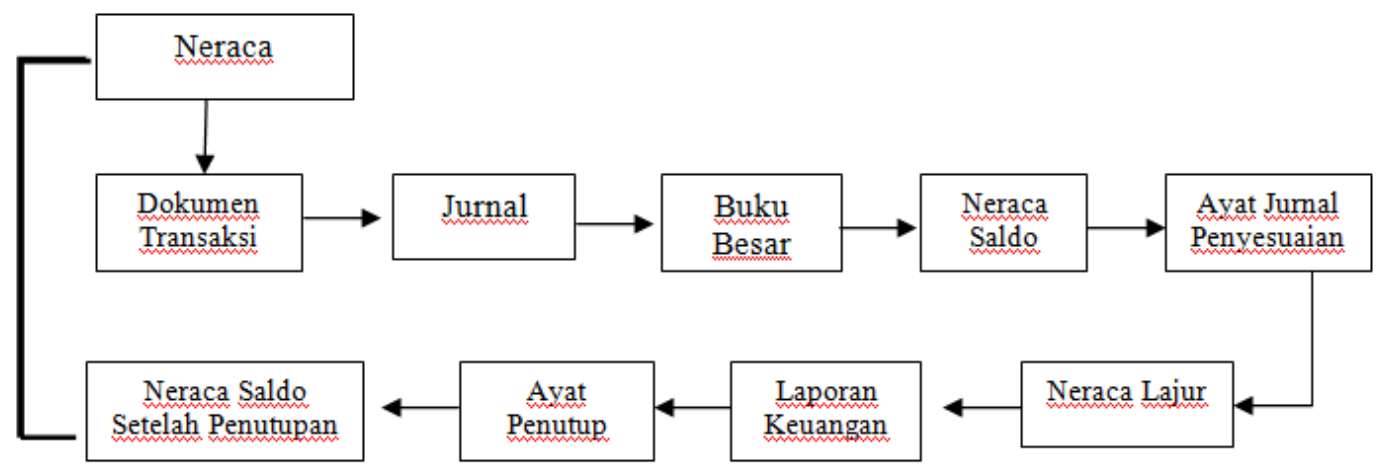

Gambar 1. Siklus Proses Akuntansi

Organisasi Nirlaba menyediakan jasa dan tidak beritikad untuk memperoleh laba, organisasi ini umumnya dibiayai dari kontribusi, perolehan dana dari endowment atau investasi, pengenaan tarif atas jasa yang diberikan dan pemberian bantuan dari pemerintah. Dalam pelaksanaan pengelolaan keuangannya suatu organisasi nirlaba dapat memperoleh suatu surplus yang merupakan selisih antara aliran kas masuk dengan aliran kas keluar.

Laporan aktivitas menyajikan jumlah perubahan aktiva bersih terikat permanen, terikat temporer, dan tidak terikat dalam suatu periode. Laporan aktivitas juga menyajikan keuntungan dan kerugian yang diakui dari investasi dan aktiva lain (atau kewajiban) sebagai penambah atau pengurang aktiva bersih tidak terikat, kecuali jika penggunaannya dibatasi oleh penyumbang, dan menyajikan beban sebagai pengurang aktiva bersih tidak terikat. Sumbangan disajikan sebagai penambah aktiva bersih tidak terikat, terikat permanen, atau terikat temporer, tergantung pada ada tidaknya pembatasan. Dalam hal sumbangan terikat yang pembatasannya tidak berlaku lagi dalam periode yang sama, dapat disajikan sebagai sumbangan tidak terikat sepanjang disajikan secara konsisten dan diungkapkan sebagai kebijakan akuntansi. Laporan aktivitas menyajikan keuntungan dan kerugian yang diakui dari investasi dan aktiva lain (atau kewajiban) sebagai penambah atau pengurang aktiva bersih tidak terikat, kecuali jika penggunaannya dibatasi. 
Laporan aktivitas menyajikan jumlah pendapatan dan beban secara bruto. Namun demikian pendapatan investasi, dapat disajikan secara neto dengan syarat beban-beban terkait, seperti beban penitipan dan beban penasihat investasi, diungkapkan dalam catatan atas laporan keuangan. Laporan aktivitas atau catatan atas laporan keuangan harus menyajikan informasi mengenai beban menurut klasifikasi fungsional, seperti menurut kelompok program jasa utama dan aktivitas pendukung. Di samping itu, organisasi nirlaba dianjurkan untuk menyajikan informasi tambahan mengenai beban menurut sifatnya. Misalnya, berdasarkan gaji, sewa, listrik, bunga, penyusutan.

Setelah mendengarkan ceramah tentang pengelolaan keuangan, maka bagian kedua adalah memberikan kesempatan kepada peserta untuk mengajukan pertanyaan dan mendiskusikan secara bersama dengan tim pengabdian. Beberapa pertanyaan yang diajukan adalah sebagai berikut:

1. Pengurus Panti Asuhan Darus-Shiddiqien NW Merta Paok belum melakukan pelaporan secara akuntabilitas dan transparasni. Apa yang harus dilakukan oleh pengurus untuk melakukan transparan dan akuntabel dalam pelaporan keuangan?

2. Format-format laporan seperti apa yang harus pengurus buat untuk dapat mengetahui dana dana yang telah masuk ke panti asuhan?

3. Bagaimana cara membuat laporan keuangan yang baik, terutama panti asuhan yang merupakan akuntansi sektor publik non profit?

Dalam menanggapi pertanyaan dari peserta pengabdian, tim pengabdian memberikan penjelasan terkait pengelolaan keuangan. Berikut adalah ringkasan jawaban atas pertanyaan yang diajukan oleh peserta pengabdian:

1. Berkaitan dengan sektor publik, organisasi harus melaporkan dana yang keluar atau pun masuk. Termasuk panti asuhan yang merupakan organisasi sektor publik dimana pelaporan keuangan berpedoman pada PSAK 45. Dalam PSAK 45 setidaknya organisasi harus membuat laporan aktivitas, laporan arus kas dan neraca. Terkadang memang sulit untuk membuat laporan-laporan tersebut, oleh karena itu setidaknya pengurus organisasi mampu membuat laporan kas keluar dan kas masuk. Aspek akuntabilitas dan transparansi pada organisasi nirlaba menjadi subjek yang sensitif dan komplek. Akuntabilitas dan transparansi organisasi nirlaba menjadi tolak ukur profesionalisme dan kredibilitasnya sebagai sebuah organisasi, terutama bagi organisasi yang bergerak dalam kegiatan non-profit. Akuntabilitas mengacu pada istilah yang luas dan mencangkup beberapa konsep. Secara sederhana, akuntabilitas merupakan bentuk tanggung jawab untuk tindakan yang diambil, mampu memberikan penjelasan dan pemahaman, mengklarifikasi, membenarkan dan menerima tanggungjawab atas tindakan yang diambil. Sedangkan transparansi merujuk pada sikap terbuka, mudah dimengerti, jujur, mudah diakses menggunakan semua media komunikasi. Panti asuhan harus melaporkan penggunaan dana karena beberapa donator terkadang ingin mengetahui penggunaan dana. Dengan melaporkan penggunaan dana dengan mencatat kas masuk maupun kas keluar sudah melakukan aspek akuntabilitas dan transparansi walaupun tidak dengan laporan lengkap.

2. Sebagian masyarakat mungkin belum mengetahui tentang adanya organisasi yayasan yang bersifat nirlaba. Kemunculan yayasan sebagai salah satu sektor keuangan di Indonesia merupakan hal yang tabu di masyarakat. Seperti yang diketahui bahwa panti asuhan juga sebagai lembaga non profit memiliki kegiatan manajemen, baik yang berkaitan dengan sumber daya manusia, keuangan dan juga kegiatan operasionalnya. Berdasarkan PSAK 45 karakteristik organisasi nirlaba terutama panti asuhan berbeda dengan organisasi bisnis. Mengingat adanya tuntutan atas akuntabilitas dan transparansi pada sektor publik serta pentingnya laporan keuangan yang disusun oleh organisasi 
nirlaba terutama pada Panti Asuhan Darus - Shiddiqien Nw. Dalam PSAK 45 terdapat 4 laporan keuangan yang dibuat yaitu: a) Laporan Posisi Keuangan, yang bertujuan untuk menyediakan informasi mengenai aset, liabilitas dan informasi lainnya;b) Laporan Aktivitas, yang tujuaannya adalah menyediakan informasi mengenai pengaruh transaksi dan peristiwa yang dapat mengubah jumlah dan sifat aset; c) Laporan Arus Kas, bertujuan untuk menyajikan informasi mengenai penerimaan dan pengeluaran kas dalam suatu periode; d) Catatan atas Laporan Keuangan, bertujuan untuk menyajikan segala informasi jumlah dan sifat aset, liabilitas dan aset netto organisasi. Namun untuk Panti Asuhan Darus - Shiddiqien Nw yang memiliki sumber daya yang kurang dalam bidang pencatatan dan pembukuan cukup membuat arus kas masuk dan arus kas keluar setiap peristiwa atau transaksi yang terjadi setiap hari.

\begin{tabular}{|lr|}
\hline Aliran Aktivitas Operasi & \\
Pendapatan : & 247.132 .875 \\
Sumbangan Donatur & 58.690 .000 \\
Pendapatan Tenda & 14.701 .000 \\
Pendapatan Kursi Plastik & 5.055 .000 \\
Pendapatan Kursi Parnekel & 8.415 .000 \\
Pendapatan Plafon Tenda & 2.974 .000 \\
Pendapatan Karpet, Tikar \& Tabir & 31.335 .000 \\
Pendapatan Truck \& Pick Up & 253.431 .000 \\
Pendapatan Tamu Putera & 22.694 .200 \\
Pendapatan Tamu Putri &
\end{tabular}

Gambar 2. Aliran Aktivitas Operasi

3. Salah satu bentuk pertanggungjawaban perusahaan kepada donatur yaitu berupa laporan keuangan. Baik untuk organisasi dalam skala besar maupun dalam skala kecil, laporan keuangan merupakan kewajiban yang harus dibuat pada setiap periode. Jika diibaratkan, laporan keuangan merupakan jantung dari sebuah organisasi. Sebagai pemilik panti asuhan, wajib bisa membaca laporan keuangan, karena laporan keuangan akan sangat membantu dalam mengetahui kondisi keuangan panti asuhan. Berikut cara mudah untuk membuat laporan keuangan sederhana bagi panti asuhan yaitu dengan membuat catatan kas masuk dan catatan kas keluar. Setelah melakukan pencatatan kas masuk dan keluar, bendahara panti asuhan dapat membuat setidaknya laporan neraca di akhir tahun sehingga dapat terlihat pengeluaran dan pemasukan selama satu tahun berjalan.

Secara umum kegiatan ini berjalan dengan baik. Adapun indikator untuk menilai keberhasilan kegiatan adalah tingkat kehadiran peserta yang sangat tinggi, animo yang besar untuk mengikuti kegiatan, tanya jawab yang aktif dan interaksi dua arah yang baik selama proses diskusi berlangsung. Sehingga diharapkan kegiatan penyuluhan dan pedampingan penyusunan pengelolaan keuangan tetap dilakukan sehingga memberikan pemahaman yang baik bagi pengurus Panti Asuhan DarrusShiddiqien NW Merta Paok. Beberapa hal yang masih kurang baik dalam pelaksanaanya akan 
ditingkatkan pada kegiatan mendatang, yaitu praktik langsung dalam bentuk pembuatan pembukuan terutama buku besar kas masuk dankas keluar.
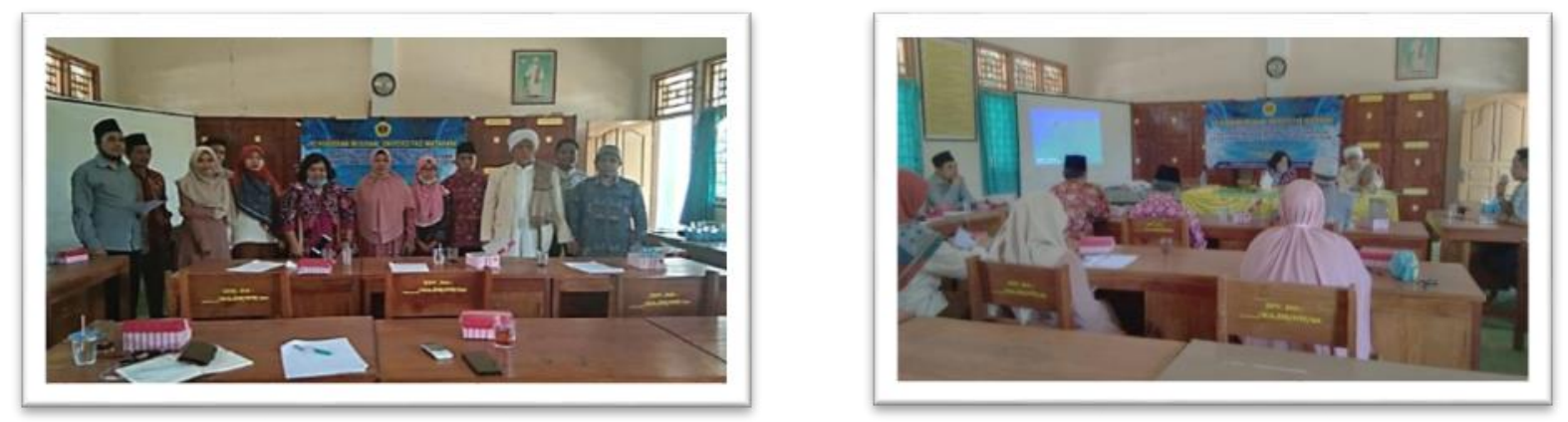

Gambar Kegiatan Pengabdian pengelolaan keuangan Panti Asuhan Darus Shiddiqien NW Mertak Paok Kabupaten Lombok Tengah

\section{KESIMPULAN DAN SARAN}

Tujuan kegiatan penyuluhan dan pelatihan tentang penyusunan pengelolaan keuangan Panti Asuhan Darus Shiddiqien NW Mertak Paok Kabupaten Lombok Tengah adalah memberikan pengetahuan bagi pengurus panti asuhan terkait pedoman pelaporan keuangan di panti asuhan dan cara membuat pencatatan pembukuan kas masuk dan kas keluar sehingga dapat membantu pemerintah dalam mewujudkan good governance di yayasan terutama panti asuhan. Kegiatan ini melibatkan 10 peserta pengurus Panti Asuhan Darrus-Shiddiqien NW Merta Paok.

Pendekatan ceramah, tanya jawab dan diskui dengan melibatkan partisipasi aktif dengan peserta pengabdian, serta menelaah penyusunan pengelolaan keuangan yang dilakukan untuk meningkatkan pengetahuan pengurus panti asihan terkait pedoman pelaporan keuangan panti asuhan, pencatatan pembukuan dan pengelolaan keuangan. Materi yang disampaikan oleh pemateri kemudian didiskusikan dalam kegiatan antara lain: pengenalan akuntansi sektor publik ,pengertian akuntansi, pencatatan pembukuan, pedoman pelaporan keuangan PSAK 45 serta macam-macam laporan keuangan.

Hasil kegiatan penyuluhan dan pelatihan tentang penyusunan pengelolaan keuangan Panti Asuhan DarusShiddiqien NW Mertak Paok Kabupaten Lombok Tengah dalam meningkatkan pengetahuan pengurus dan pentingnya dalam pencatatan pembukuan oleh bendahara panti asuhan. Indikator keberhasilan yang digunakan dalam kegiatan ini yaitu tingkat kehadiran peserta pengabdian yang sangat tinggi, animo yang besar untuk mengikuti kegiatan, tanya jawab yang aktif serta interaksi dua arah yang baik antara tim pengabdian dan peserta selama proses diskusi berlangsung. Oleh karena itu, kegiatan penyuluhan dan pelatihan ini diharapkan selalu dapat dilakukan sehingga membantu memberikan pemahaman yang lebih baik terkait pedoman serta pengelolaan keuangan panti asuhan kepada pengurus panti asuhan. Beberapa hal yang masih kurang baik dalam pelaksanaannya akan ditingkatkan pada kegiatan mendatang, yaitu praktik dalam pencatatan pembukuan dan pembuatan laporan keuangan khusus panti asuhan.

\section{Ucapan Terima Kasih}

Tim pengabdian mengucapkan terima kasih kepada Lembaga Penelitian dan Pengabdian kepada Masyarakat (LPPM), Badan Pengkajian dan Pengembangan Ekonomi dan Bisnis (BP2EB), dan Fakultas Ekonomi dan Bisnis melalui sumber dana BLU (PNBP) Universitas Mataram yang telah memberi kesempatan dan bantuan kepada tim pengabdian untuk melakukan kegiatan ini. 


\section{DAFTAR PUSTAKA}

Dewi, Eka, Kusuma. 2020. Analisis Penerapan PSAK NO 45 Tentang Pelaporan Keuangan Entitas Nirlaba Pada Panti Asuhan Al-Husna Bukit Pamulang Indah. Jurnal Akuntansi Barelang. Vol. 4 No. 2.

Fahmi, Redista. 2016. Penerepan Laporan Keuangan Pada Yayasan Panti Asuhan Yatim Piatu dan Fakir Miskin Daarul Aytam Situbondo. Universitas Muhammadiyah Jember.

Fitria, Yunita. 2017. Akuntabilitas pada Organisasi Religi: Studi Kasus Masjid-Masjid di Balikpapan, Kalimantan Timur. Jurnal Akuntabel Vol. 14 No.1.

Nainggolan, Pahala. 2005. Akuntansi Keuangan Yayasan dan Lembaga Nirlaba Sejenis. Penerbit PT. Raja Grafindo Persada: Jakarta. 